\title{
SENSIBILIDADES ENFRENTADAS
}

\section{Tarkovski o Malick, tiempo o montaje, icono o símbolo}

\author{
Pablo Alzola Cerero \\ Universidad Rey Juan Carlos, Madrid
}

Resumen: En presente análisis estudia la posibilidad de vincular el cine de Andréi Tarkovski y Terrence Malick con dos sensibilidades específicas, esto es, con dos modos de concebir el arte en relación con la fe cristiana, siguiendo las reflexiones contenidas en el ensayo "Qué y cómo" de Fernando Inciarte. La hipótesis aquí desarrollada plantea, por un lado, la asociación de la obra de Tarkovski con una sensibilidad icónica y, por otro, la de la obra de Malick con una sensibilidad protestante. Este vínculo no se basa tanto en el contenido (plano conceptual), sino, sobre todo, en la forma artística (plano poético).

Palabras clave: Andréi Tarkovski, Terrence Malick, Fernando Inciarte, cine, icono, protestantismo.

\section{Sensibilities opposite. Tarkovski or Malick, Time or Assembly, Icon or Symbol}

Abstract: This analysis examines the possibility of connecting the cinema of Andrei Tarkovsky and Terrence Malick with two specific sensibilities, i.e. two manners of understanding the relationship between art and Christian faith, following the insights contained in Fernando Inciarte's essay "Qué y cómo". The hypothesis unfolded here suggests, on one hand, the connection of Tarkovsky's oeuvre with iconic sensibility and, on the other, Malick's films with Protestant sensibility. This link is not so much based on the narrative content (conceptual level), but rather on the artistic form (poetic level).

Keywords: Andrei Tarkovsky, Terrence Malick, Fernando Inciarte, Film, Icon, Protestantism. 
Recibido: 30/3/2017 Aceptado: 10/6/2017

En su ensayo titulado "Qué y cómo", Fernando Inciarte indaga la capacidad del arte para lograr una difícil reconciliación de lo que, a primera vista, parecen realidades opuestas: "la fe y la cultura, el arte y el cristianismo, la vida y la muerte o, según por dónde se mire, la muerte y la vida” (2016: 40). El punto de partida para plantear esta oposición es la situación del protagonista del ensayo — referido por Inciarte como "nuestro hombre"-, quien, en último término, no es sino el desdoblamiento ficticio del autor, y la condición de posibilidad para hacer que un texto filosófico pueda desenvolverse en forma de relato. Al mismo tiempo, el singular modo de argumentar de Inciarte conjuga la narrativa en torno a "nuestro hombre" con el constante recurso a las analogías, donde los analogados principales son posturas teológicas, desde las cuales se derivan modos dispares de articular la reconciliación (o no reconciliación) entre fe y cultura, Dios y mundo, y otras dicotomías similares. En cualquier caso, Inciarte no busca hacer teología —a propósito

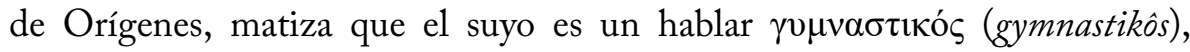

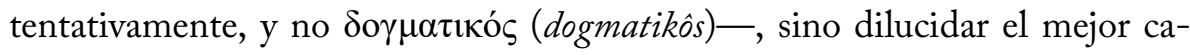
mino que tiene el arte para dar con la realidad; en este sentido, recurrir a la teología no supone una evasión del verdadero problema, sino la voluntad de querer abordarlo hasta sus últimas consecuencias.

De entre las diferentes manifestaciones artísticas aludidas por Inciarte, las reflexiones aquí propuestas se centran en el arte cinematográfico. En su breve aproximación al cine, Inciarte acude a la filmografía del cineasta ruso Andréi Tarkovski, así como a sus reflexiones sobre "el arte, la estética y la poética del 
cine", recogidas en su ensayo titulado Esculpir en el tiempo, que Inciarte cita como El Tiempo sellado ${ }^{1}$. Tal y como explican Orellana y Lucena, este libro defiende una "concepción del séptimo arte como una propuesta que se le hace al espectador para que este pueda recuperar el significado de la propia experiencia a la luz de lo que se le presenta en la pantalla" (2010: 243). Tarkovski entendía el cine como un medio completamente diferente de la literatura o de la filosofía, capaz de proporcionar al espectador un privilegio que no ofrecen las otras dos:

El privilegio de sentir como vida propia aquello que se está desarrollando en pantalla, de asumir una experiencia fijada de modo temporal como una experiencia propia, profundamente personal, de poner la propia vida en relación con lo que se muestra en la pantalla (1991: 211).

Para el cineasta ruso, la vocación del arte cinematográfico es la de ser una fuente de significado vital a la que el espectador accede por "un conocimiento que viene más del corazón que de la cabeza, que tiene que ver más con la sensibilidad que con el concepto" (2016: 104-105), como apunta Inciarte. Por ello, el cine no puede reducirse a ilustrar una idea especulativa o imponerla al público. "Lo mío es hablar en imágenes vivas, no en juicios. Yo tengo

${ }^{1}$ Inciarte utiliza la edición alemana: Die versiegelte Zeit. Gedanken zur Kunst, zur Ästhetik und Poetik des Films (korrigierte Ausg. der 2. Auflage 1986; Ullstein Sachbuch, Frankfurt M./Berlin 1988). La edición castellana aquí citada es una traducción del alemán por Enrique Banús, supervisada por J.M. Gorostidi: Esculpir en el tiempo, Madrid, Rialp, 1991. A diferencia de Inciarte, aquí empleamos el título y la grafía de esta última edición. 
que crear la vida como tal, no tengo que tratarla" (1991: 70), dice Tarkovski, haciéndose eco de unas palabras de Nikolái Gogol.

Los filmes de Tarkovski evocan, en cierto sentido, el cine realizado al otro lado del Atlántico por el cineasta estadounidense Terrence Malick. La inclusión de Malick en estas reflexiones no es algo fortuito: también sus películas —de modo especial sus últimas tres obras de ficción: El árbol de la vida (The Tree of Life, 2011), To the Wonder (2012) y Knight of Cups (2015) — aspiran a explicar al hombre "cuál es el motivo y objetivo de su existencia en nuestro planeta. O quizá no explicárselo, sino tan solo enfrentarlo a este interrogante" (Tarkovski, 1991: 60). Tanto Malick como Tarkovski comparten, a través de las imágenes, el nervio central que vertebra el citado ensayo de Inciarte, "Qué y cómo": la posible conciliación de fe y cultura, arte y cristianismo. No obstante, sus respectivas aproximaciones al problema difieren significativamente, en tanto que responden a dos sensibilidades diferentes. Así, el objetivo de este texto consiste en analizar algunos elementos estilísticos y narrativos de su cine en relación con la sensibilidad que los anima, partiendo de una doble hipótesis que quedará más explicitada en el siguiente epígrafe: a saber, que el cine de Tarkovski pertenece a una sensibilidad icónica, mientras que el cine de Malick pertenece a lo que el filósofo español llamaría sensibilidad nestoriana o, lo que es casi lo mismo, protestante.

\section{Bizantinos frente a nestorianos: Tarkovski frente a Malick}

Sirva recordar, a modo de síntesis, las tres principales posturas teológicas mencionadas por Inciarte en su ensayo, distintas unas de otras en su forma 
de entender la relación que se da entre las dos naturalezas de Jesucristo. Como apunta el filósofo, de cada una de estas posturas se sigue una sensibilidad particular, esto es, un modo concreto de concebir el arte y su relación con la fe cristiana.

Para los arameos monofisitas, en la Persona de Jesucristo la naturaleza humana no se mezcla con la divina; al contrario, la humanidad queda borrada por la divinidad, igual que "lo infinito hace desaparecer a lo finito que se pone en contacto con él" (Inciarte, 2016: 42). Como consecuencia de esta concepción de la Segunda Persona de la Trinidad, en la que la humanidad ha sido disuelta, la suya es una religión sin cultura. No son iconoclastas, pero la calidad del arte religioso les tiene completamente sin cuidado. Junto a los monofisitas, Inciarte menciona brevemente a los nestorianos, que son su polo opuesto. Estos sostienen la oposición radical de las dos naturalezas en la Persona de Jesucristo, hasta tal punto que parecen admitir la existencia de dos personas, desmantelando así la doctrina de la Encarnación del Verbo. A este respecto, conviene citar las palabras exactas con las que Inciarte presenta el nestorianismo como un anticipo del protestantismo:

Según ese modelo [nestoriano] no hay o no tiene por qué haber interferencia alguna entre los dos planos, el divino y el humano, el de lo sagrado y el de lo profano; los dos corren paralelos. En esto el nestorianismo constituye una anticipación de la doctrina protestante de los dos reinos, el de la gracia y el de la naturaleza, ajenos por completo uno del otro. La naturaleza está tan corrompida que la gracia no tiene como si dijéramos fuerza para penetrar en ella y transformarla (2016: 131). 
En este misma línea, Paul Schrader señala cómo "la Iglesia protestante, tomando como propio el texto que dice 'no tendrás otro Dios que a mî (Éxodo 20,3), prohíbe cualquier plasmación de imágenes”, pues considera que "la unidad ha sido hecha pedazos por la caída del hombre que, dominado por el pecado, no puede ya describir lo santo" (1998: 130). Se entiende que, llevado hasta sus últimas consecuencias, el protestantismo sea semilla de iconoclastia; en el caso de un protestantismo más atenuado - de cuño episcopaliano, como se verá que es el caso de Malick-, este no rehúye las manifestaciones artísticas, aunque en ellas se tiende acentuar esta contradicción entre naturaleza y gracia.

El cristianismo bizantino o griego-ortodoxo es la tercera posición teológica aludida, que Inciarte resume con una frase tomada del artista Josef Albers: "La apariencia es lo único que no engaña [Nur der Schein trügt nicht]" (2016: 40). En efecto, la idea de belleza propia de la ortodoxia es del todo singular: esta no tiene como sinónimo lo armonioso, lo bonito o lo agradable; más bien, la belleza se entiende como manifestación. "Manifestación sin más", dice Inciarte. "No manifestación de algo que se encuentre detrás de ella. La manifestación y lo manifestado coinciden en la belleza así entendida" (2016: 43). Esta concepción tiene como firme punto de apoyo la doctrina de la Encarnación: Jesucristo no representa a Dios ni encarna una imagen simbólica de la divinidad, sino que es Dios mismo; "El que me ha visto a mí, ha visto al Padre" (Juan 14, 9), dice de sí. En Él apariencia y realidad se corresponden de un modo pleno: no hay nada oculto tras la superficie, todo comparece en ella para aquel que es capaz de contemplar. En consonancia con esta postura, el icono —elemento central del arte ortodoxo- busca "una presencia inme- 
diata, opuesta a la mera representación [de la divinidad]" (Inciarte, 2004: 146). De este modo, señala Inciarte, "lo representado en un icono está de algún modo también presente en él” (2016: 43).

Una vez bosquejadas estas tres posturas teológicas, con sus correspondientes formas de entender el arte, es posible desarrollar un poco más la hipótesis antes apuntada. En primer lugar, es el propio Inciarte quien plantea la posibilidad de asociar el cine de Andréi Tarkovski con la posición icónica ortodoxa: "El lugar espiritual de Tarkovski es el de un cristianismo icónico para el que las apariencias no engañan" (2016: 113), sostiene. No parece demasiado difícil establecer esta conexión, al menos en el nivel más conceptual: el segundo largometraje de Tarkovski, Andréi Rublev (Андрей Рублёв, 1966), trata sobre el célebre pintor de iconos ruso de finales del siglo XIV y comienzos del XV; además, algunas escenas de las películas de Tarkovski nos muestran imágenes icónicas o personajes hablando sobre dichas imágenes. El relato de Nostalgia (Nostalghia/Ностальгия, 1983) arranca precisamente con la visita del poeta ruso Andréi Gorchakov (Oleg Yankovsky) y la traductora italiana Eugenia (Domiziana Giordano) a la iglesia en la que se encuentra el fresco de la Madonna del parto, obra de Piero della Francesca, el cual, si bien no es estrictamente un icono, sí desempeña una función sagrada en la película. Por otra parte, la última cinta de Tarkovski, Sacrificio (Offret, 1986), presenta una escena donde su protagonista Alexander (Erland Josephson) 
contempla y comenta un libro con reproducciones de iconos, regalo del día de su cumpleaños ${ }^{2}$.

No obstante, sería un error fundar la supuesta sensibilidad icónica del cine de Tarkovski sobre una serie de referencias conceptuales al arte de los iconos. Se trataría de una explicación más especulativa que poética, fruto "de una banalización de la realidad vital, en sí mucho más compleja” (Tarkovski, 1991: 38). Estaríamos abordando este cine únicamente desde el punto de vista de su contenido (del qué), como si fuera un texto filosófico, dejando a un lado el cómo, la sensibilidad artística que vivifica ese qué. Ciertamente, en el caso de existir una relación entre el cine de Tarkovski y el arte icónico, Inciarte y el cineasta ruso coincidirían en referir esta relación como eminentemente poética: fundada sobre todo en la forma (el cómo), capaz de superar el contenido y vivificarlo. Valgan de apoyo las siguientes palabras de Tarkovski:

Cuando un artista crea su imagen, está asimismo superando su pensamiento, que es una nada en comparación con la imagen del mundo captada emocionalmente, imagen que para él es una revelación. Pues el pensamiento es efímero, y la imagen, absoluta (1991: 64).

2 Alexander: “¡Fantástico! ¡Qué gran refinamiento! Qué sabiduría y espiritualidad, y al mismo tiempo inocencia infantil. Profundidad e ingenuidad a la vez. Increíble. Como una plegaria. Todo esto se ha perdido. No somos capaces ni de rezar". (La traducción de la versión original sueca se corresponde con los subtítulos en castellano disponibles en la edición en DVD distribuida en España por Cameo, Dep. Legal B-42033-2019). 
Este carácter absoluto de la imagen —al cual aspira el cine de Tarkovski- es, salvando las distancias, el mismo que presentan los iconos, en cuya superficie está ya todo, nada queda oculto. En este sentido, la supuesta relación entre cine e icono en Tarkovski habría de partir de aquí: de "la lógica de lo poético" (Tarkovski, 1991: 37). Por ello, esta indagación se centrará principalmente en analizar este cine desde un punto de vista formal (cómo), prestando atención, al mismo tiempo, a algunos elementos del contenido narrativos— que son vivificados — resueltos, como diría Inciarte (2016: 60)_ por el elemento formal.

La segunda parte de la hipótesis aquí planteada es, posiblemente, la más arriesgada, pues no se sustenta sobre ninguna aserción previa, como sucede con el caso de Tarkovski y la sensibilidad icónica que Inciarte le atribuye. Del mismo modo que hay una sensibilidad que anima en cine de Tarkovski, también es posible vincular la obra de Terrence Malick con una sensibilidad específica: la protestante o, siguiendo a Inciarte, nestoriana. En especial, esta relación había que buscarla en el plano poético, sin desdeñar por ello algunos elementos puramente narrativos que comparten un sentido concomitante con el anterior plano.

Ahora bien, a propósito de esta hipotética relación, cabría preguntar cómo se manifiesta dicha sensibilidad en la filmografía de Malick. Sin ánimo de simplificar lo que —en las siguientes páginas — será objeto de estudio, sirva esta síntesis: en sus últimos tres largometrajes de ficción, Malick se vale de dos recursos poéticos - el montaje fragmentado y la voz en off - para acentuar la contradicción por encima de la resolución, en el caso del montaje, y la interioridad del personaje sobre su actuar, en el caso de la voz en off. 
Siguiendo las reflexiones de Paul Schrader en El estilo trascendental en el cine (1998 [1972]), se mostrará cómo este cine pone el énfasis sobre la dispari$d a d^{3}$, esto es, sobre el enfrentamiento de realidades irreconciliables. A su vez, esta asociación poética se apoya sobre algunas claves referentes al contenido: en El árbol de la vida, por ejemplo, varios personajes ponen en palabras la contradicción entre los reinos de la naturaleza y de la gracia - propia del protestantismo, como apunta Inciarte- Tal es el caso de la voz en off de Mrs. O'Brien (Jessica Chastain) al comienzo del filme ${ }^{4}$, o del joven Jack O'Brien (Hunter McCracken) en la secuencia que narra su pérdida de la gracia 5 .

3 "La disparidad es la paradoja de lo espiritual existente dentro de lo físico y no puede ser resuelta por medio de ninguna lógica terrenal o emoción humana. Debe [...] ser aceptada o rechazada" (Schrader, 1998: 106).

${ }^{4}$ Mrs. O'Brien: "Las monjas nos enseñaron que hay dos caminos en la vida: el camino de la naturaleza y el camino de la gracia. Debes elegir cuál vas a seguir. La gracia no busca contentarse a sí misma. Acepta ser menospreciada, olvidada, disgustada. Acepta insultos e injurias. La naturaleza solo quiere contentarse a sí misma; y lograr que otros también la agraden. Le gusta dominarlos, tener su propio camino. Encuentra motivos para estar infeliz cuando todo el mundo resplandece a su alrededor, cuando el amor sonríe a través de todas las cosas" (La traducción de la versión original inglesa es del autor). Según apunta Peter J. Leithart (2013: 38), Malick parece estar parafraseando una cita de La imitación de Cristo, de Tomás de Kempis (Libro III, cap. 59).

${ }^{5}$ Jack O'Brien: “What I want to do I can't do, I do what I hate [Lo que quiero hacer, eso no puedo hacerlo; hago aquello que aborrezco]" (La traducción es del autor). Según indica Natasha Hay (2014), estas palabras son un remedo de aquellas otras de san Pablo: "Porque no hago lo que quiero, sino lo que aborrezco, eso hago” (Romanos 7,15). En la versión King 
La breve extensión de esta investigación impide llevar a cabo un análisis de la filmografía completa de Tarkovski y Malick, que en ambos casos consta de siete largometrajes de ficción, aunque en el caso de Terrence Malick hay futuros títulos anunciados. Dada la necesidad de acotar el objeto de estudio, el análisis que sigue se centrará únicamente en una película de cada director, aquella que consideramos más representativa de su posible asociación con una sensibilidad específica: así, se ha seleccionado el filme Stalker (Ста́лкер, 1979) de Tarkovski y El árbol de la vida de Malick. Como se mostrará a continuación, la peculiar unidad estética de Stalker la hace especialmente idónea para relacionarla con la sensibilidad icónica. Por otra parte, tal y como sostiene Peter J. Leithart, "la amplitud temática de Malick y su explotación de las capacidades del cine hacen que El árbol de la vida sea única en su especie" (2013: 8). Además, su clara impronta biográfica la convierte en una obra de singular relevancia en el conjunto de su filmografía: "Es un homenaje cinematográfico a Larry Malick [hermano del cineasta, fallecido a los diecinueve años], un réquiem en celuloide" (Leithart, 2013: 3). La cita del Libro de Job ${ }^{6}$ con que arranca la película la sitúa en un horizonte trascendente, propicio para articular un diálogo entre fe y arte.

James de la Biblia, posiblemente la que mejor conoce Malick: "For what I would, that do I not; but what I hate, that do I" (Romans 7,15).

6 "Where were you when I laid the foundations of the earth? [...] When the morning stars sang together, and all the sons of God shouted for joy? [¿Dónde estabas tú cuando yo cimentaba la tierra [...], cuando cantaban a una las estrellas matutinas y aclamaban todos los ángeles de Dios?]” (Job 38, 4.7). Aquí Malick emplea la versión King James. 


\section{Stalker: un icono hecho de tiempo}

Como se ha anticipado, la posible sensibilidad icónica de la obra de Tarkovski no radica en el plano conceptual. Tampoco de trata de trasladar al cine el lenguaje pictórico de los iconos. En Esculpir en el tiempo, el cineasta ruso se refiere a los problemas que entraña esta última solución, los cuales se le presentaron por primera vez en la realización de su película sobre Andréi Rublev:

Si hubiéramos seguido el camino de la reconstrucción de las tradiciones pictóricas, del mundo pictórico de aquel tiempo, lo que hubiéramos obtenido habría sido una realidad de la vieja Rusia estilizada y convencional, que en último caso hubiera recordado las miniaturas o los iconos de aquel entonces. Para el cine eso habría sido un camino equivocado. [...] Nunca he conseguido comprender cómo se puede estructurar una puesta en escena sobre la base de un cuadro (Tarkovski, 1991: 101).

Se trataba, por el contrario, de dar con la realidad espiritual que presenta el icono, aquella que sigue viva a pesar del paso de los siglos. Así, por ejemplo, el célebre icono de la Trinidad de Rublev se puede ver como "ejemplo del estilo de una época en pintura. Pero es indudable que existe otra forma de recibir este testimonio histórico: el abrirse al contenido humano y espiritual de la Trinidad, que nos es comprensible y está vivo para nosotros" (Tarkovski, 1991: 102). ¿De dónde surge, entonces, ese contenido vivo del icono, si no es del lenguaje pictórico? Surge del carácter absoluto de la imagen, al cual también aspira, a tenor de Tarkovski, la imagen cinematográfica, tal y como 
sostiene repetidas veces a lo largo de su ensayo: "La imagen tiende hacia lo infinito y conduce hacia lo absoluto [...]. Independientemente de que no podamos percibir el universo en su totalidad, la imagen es capaz de expresar esa totalidad" (1991: 127-128). Y, un poco más adelante, afirma: "La imagen es algo fantástico. En cierto sentido es incluso más rica que la propia vida, en el sentido en que expresa la idea de la verdad absoluta" (1991: 137).

El siguiente paso es ver cuál es, en opinión de Tarkovski, el camino por el que el cine expresa este carácter absoluto, "la especificidad de este arte" (1991: 103), en palabras del artista ruso. En el capítulo de su ensayo titulado "El tiempo sellado", el director lanza esta pregunta y propone una respuesta: "¿Y en qué reside la naturaleza de un arte fílmico propio de un autor? En cierto sentido, se podría decir que es el esculpir el tiempo" (Tarkovski, 1991: 84). Así pues, el elemento específico del cine —la condición de posibilidad del carácter absoluto de sus imágenes, podría decirse- es el tiempo. Fernando Inciarte destaca esta misma idea en sus reflexiones sobre el cine: "El presente, lo único real del tiempo, pasa, pero la cámara lo detiene, lo sella. El tiempo real pasa, es paso, pero la imagen lo conserva en su pasar" (2016: 108). Explica Inciarte que en el cine hay dos tiempos: el tiempo real que dura la película y el tiempo ficticio de la acción. Curiosamente, en Stalker parece darse una confluencia casi total de estos dos tiempos, como si el cineasta hubiera querido resaltar, por esta vía, lo específico del cine. Vale la pena citar las palabras de Tarkovski al respecto:

Para mí fue extremadamente importante que en esta película el guion mantuviera la unidad de tiempo, espacio y acción. [...] En Stalker no quería que hubiera 
ningún salto temporal entre las diversas partes. Pretendía que aquí todo el transcurso del tiempo se pudiera percibir dentro de un solo plano, que el montaje indicara en este caso tan sólo la continuación de los hechos. [...] Y con ello quería convencer aún más al público de que el cine — como instrumento artístico- tiene sus propias posibilidades (1991: 219).

Este principio es el que vertebra toda la película y, en gran medida, determina la estructura del relato, configurado como un viaje. En efecto, Stalker es el viaje de dos hombres de personalidades contrapuestas -el Escritor (Anatoli Solonitsyn), de carácter pasional y bohemio, y el Profesor (Nikolái Grinkó), frío y racional—, guiados por un tercero, el Stalker (Aleksandr Kaidanovski). Este último ha consagrado su vida a la tarea de guiar a los hombres que lo pidan a través de una región desolada por un fenómeno paranormal, conocida como "la Zona". La meta del viaje es una habitación donde se cumplen los deseos más íntimos de todo aquel que entre en ella. Así, esta premisa argumental permite explotar las capacidades que tiene el cine de sellar el tiempo en su pasar. La dinámica creada por el viaje de los tres personajes, filmado casi a tiempo real, contribuye a generar una presión temporal dentro de cada plano.

Desde el punto de vista del espacio - de su disposición en el plano cinematográfico-, la perspectiva de la cámara acentúa este protagonismo del

7 "La consistencia temporal que recorre un plano, la tensión del tiempo que crece o se va 'evaporando', eso lo podemos llamar la presión del tiempo dentro de un plano” (Tarkovski, 1991: 143). 
tiempo. A lo largo de la película se repite la misma composición: planos generales estáticos, donde sus elementos crean en ocasiones una cierta simetría. Dichos planos tienen, casi siempre, un tempo lento, como si a través de esta demora, quietud y equilibrio solo se quisiera llamar la atención del espectador sobre una sola cosa: el paso del tiempo. Decía Tarkovski que si se incrementa la duración de una escena resulta aburrida, y que si se la incrementa más crece el interés; pero que, si se la incrementa aún más, "surge una nueva calidad e intensidad" (Tarkóvskaya, 1988: 156). De este modo, la posición estática y omniabarcante de la cámara, unida al tiempo prolongado, hace surgir ese carácter absoluto de la imagen cinematográfica donde, de modo parejo al icono, todo comparece en la densidad de su superficie.

Estos recursos, por los que Tarvkoski invita al espectador a detener su mirada sobre las imágenes filmadas, podrían llevarnos a malinterpretar dichas imágenes en clave simbólica. En este sentido, podría pensarse que la Zona es un símbolo de la desolación interior de los hombres que la atraviesan, la habitación a la que se dirigen un símbolo de la conciencia individual o el perro negro un símbolo de la fidelidad del Stalker a su misión. No obstante, el cineasta no busca simbolizar nada: "A menudo se me ha preguntado qué simboliza exactamente la Zona y hay quien se ha lanzado a las más aventuradas hipótesis y sospechas. [...] En ninguna de mis películas se simboliza algo. La Zona es sencillamente la Zona" (Tarkovski, 1991: 223). Caer en el simbolismo supondría privilegiar lo conceptual por encima de lo formal; esto traería, en opinión del artista ruso, una perversión de la naturaleza del cine, cuya fuerza y pureza "se muestran no en la agudeza simbólica de las imágenes, por muy audaces que estas sean, sino en el hecho de que las imágenes 
expresan la concreción e irrepetibilidad de un hecho real" (Tarkovski, 1991: 94). Esta característica apoya la asociación del cine de Tarkovski - y de Stalker, en este caso concreto- con la sensibilidad icónica. En el icono, la apariencia no es indicio de otra cosa que se encuentre escondida: es apariencia y nada más o, como decía Josef Albers, es lo único que no engaña.

Esto no quiere decir que el carácter absoluto de la imagen icónica sea de por sí suficiente para que cualquiera pueda apreciar ese todo que en ella comparece. Este es, precisamente, uno de los conflictos que atraviesa el relato de Stalker: la capacidad o incapacidad de los visitantes de la Zona -el Escritor y el Profesor- para recibir de ella una revelación que les transforme. Como apunta Colin Heber-Percy, "la Zona es un espacio apocalíptico" (2016), en el

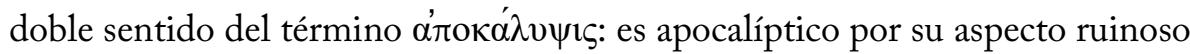
pero, sobre todo, es apocalíptico por ser "un lugar de revelación, significado literal de $\alpha$ 'лока́ $\lambda v \psi 1 \varsigma$. La Zona es en sí misma reveladora; es el lugar de un descubrimiento, de un desvelamiento" (Heber-Percy, 2016). Esta última característica queda remarcada por la posición de la cámara aquí descrita su posición estática y su demora-, pero también por elementos no formales, como algunos monólogos o diálogos de la película. Destaca, entre todos ellos, el breve monólogo del Stalker durante el descanso que hacen a mitad de camino:

Stalker: Ese mismo día, iban dos de ellos a una aldea que distaba alrededor de sesenta estadios de... llamada... y estaban conversando entre sí sobre todas estas cosas. Y mientras estaban conversando y discutiendo, Él mismo se les acercó y empezó a caminar con ellos. Pero sus ojos eran incapaces de reconocerle. Y Él les 
Sensibilidades enfrentadas

dijo: “¿Qué son esas palabras... que intercambiáis entre vosotros, y por qué estáis tristes?". Y uno de ellos, llamado... ${ }^{8}$

Es evidente que el Stalker está citando —omitiendo lo particular y realzando lo universal- el relato sobre los discípulos de Emaús, recogido por el Evangelio según san Lucas $(24,13-18)$. Una vez más, esta cita podría dar lugar a una interpretación simbólica: el Stalker es Cristo, y sus acompañantes los dos discípulos de Emaús - Cleofás y su amigo- En cambio, siguiendo la línea de Tarkovski, la cita nos aleja del simbolismo para indicarnos la posibilidad de una revelación análoga a la narrada por san Lucas: una revelación para los viajantes, pero también para el espectador. Si bien en la imagen icónica todo comparece en la superficie, como afirma Inciarte, hacen falta ojos capaces de ver aquello que se revela. Así lo explica Inciarte en su obra Imágenes, palabras, signos:

$\mathrm{El}$ camino es largo. No es que baste con abrir los ojos. Si los hubiéramos podido abrir nada más nacer, tal vez. Es más bien que a uno le tienen que enseñar a abrir los ojos, porque eso es lo más difícil de todo. Abrir los ojos y ver lo que se ve, y nada más que eso (2004: 164).

En este contexto, el viaje descrito por Stalker se nos descubre como un camino de purificación de la mirada (“¿Estáis despiertos?”, pregunta el Stalker a sus acompañantes una vez terminado su monólogo). Se entiende que

\footnotetext{
${ }^{8}$ Traducción del autor a partir de los subtítulos ingleses de T. Kameneva.
} 
Tarkovski haga aquí una referencia explícita a Emaús, que es —según afirma Joseph Ratzinger- la escena evangélica más significativa para comprender la naturaleza de la imagen icónica y el camino de ascesis de la mirada necesario para contemplarla:

En un primer momento, los discípulos no lo reconocen [a Cristo]. Tienen que dejarse conducir a una nueva forma de ver que les va abriendo los ojos desde dentro [...]. El relato más significativo al respecto, es probablemente, el de los discípulos de Emaús. Primero queda transformado su corazón, para que puedan reconocer los acontecimientos exteriores de la Escritura [...]. Después deben retener al misterioso compañero de camino, ofrecerle su hospitalidad, para que, al partir el pan, suceda, de modo inverso, lo que les ocurrió a Adán y a Eva cuando comieron del fruto del árbol de la ciencia: que se les abran los ojos. [...] $\mathrm{El}$ icono conduce al que lo contempla, mediante esa mirada interior que ha tomado cuerpo en el icono, a que vea en lo sensorial lo que va más allá de lo sensorial y que, por otra parte, pasa a formar parte de los sentidos (Ratzinger, 2001: 160-161).

A la luz de estas consideraciones, se comprende en qué sentido las imágenes en movimiento de Stalker se revelan como imágenes icónicas, que aspiran a entablar con el espectador una relación análoga a la que proviene del icono, tal y como la presenta Ratzinger. El propio Tarkovski explicita la sensibilidad icónica de su cine, cuando señala que para él el arte es "en esencia algo casi religioso, una toma de conciencia sagrada de un alto deber espiritual" (1991: 196). 
Sensibilidades enfrentadas

\section{El árbol de la vida: la disparidad del montaje}

A diferencia de Tarkovski, Terrence Malick no ha escrito unas reflexiones sobre la poética de su cine; tampoco ha hablado de ella en ningún entrevista — no ha concedido ninguna desde el año $1979^{9}$ —. Por este motivo, resulta más arriesgado plantear una posible relación entre el cine de Malick y una sensibilidad específica: la nestoriana o protestante, según ha sido aquí esbozada a partir del texto de Inciarte. En cualquier caso, se trata de una hipótesis que no carece de cierta fundamentación, al menos si se tiene en cuenta el contexto cultural y religioso del que proviene el cineasta texano. Malick fue educado en la escuela episcopaliana de St. Stephen, en Austin (Cfr. Kendall y Tucker, 2011: 5), a cuya confesión cristiana todavía pertenece, según indican diversas fuentes.

No parece casualidad, por tanto, que El árbol de la vida - película que "recurre a la experiencia de infancia de Malick en Texas"10, como señala Steven Rybin (2012: 178) — aluda de forma explícita en varias escenas — muy breves - a la fe episcopaliana de la familia O'Brien, la familia vicaria de Malick: principalmente, la salida del funeral por R.L. (Laramie Eppler), el hermano de Jack que tocaba la guitara -instrumento que también tocaba

${ }^{9}$ Realizada por Yvonne Baby y publicada en Le Monde (17.05.1979) (Cf. Maher, 2014: 2123).

${ }^{10}$ Conocemos que la película se sitúa en el hogar de infancia de Malick en Waco, Texas, mediante dos detalles visuales fugaces: el nombre del periódico local que Mr. O’Brien lee y las letras de un camión de insecticida. 
con gran destreza Larry Malick, hermano del cineasta ${ }^{11}$-; el bautismo de Jack; la recepción del sacramento de la confirmación por parte de los tres hermanos O’Brien y el sermón del ministro episcopaliano (Kelly Koonce) sobre el Libro de Job durante un servicio dominical. A modo de aclaración, sirva apuntar que la Iglesia episcopaliana es la representante de la Comunión anglicana en Estados Unidos y Canadá, principalmente. Pese a las numerosas tradiciones católicas conservadas por episcopalianos y anglicanos - el propio Inciarte refiere "el refinamiento de la liturgia episcopaliana, como el de la anglicana en otras partes del mundo" (2016: 121)—, en ambas denominaciones subyace un poso de teología protestante innegable, como se mostrará en lo que sigue.

Una vez más, siguiendo la línea marcada por el ensayo de Inciarte que guía este análisis, es preciso buscar la relación de la obra Malick —y de El árbol de la vida, más concretamente- con la sensibilidad protestante no tanto en el plano biográfico, sino en el plano poético; no en lo conceptual (el qué), sino en lo formal (el cómo) o, mejor dicho, en el concepto vivificado por la forma. En este sentido, hay dos rasgos relevantes que Inciarte atribuye a la sensibilidad protestante - en analogía con el nestorianismo- y que encuentran su expresión poética en El árbol de la vida: por un lado, la ya aludida "doctrina protestante de los dos reinos, el de la gracia y la naturaleza, ajenos

${ }^{11}$ A finales de los años 60, Larry Malick, el hermano pequeño de la familia, fue a España a estudiar guitarra con el maestro Andrés Segovia. En 1968, presa de la frustración, se rompió las dos manos y, poco después, se suicidó. Tenía 19 años, la misma edad con la que muere R.L. en El árbol de la vida, según lo da a entender el relato (Cf. Leithart, 2013: 3). 
por completo uno del otro" (Inciarte, 2016: 131); por otro lado, el subjetivismo característico de esta sensibilidad, por el que la conciencia individual se relaciona directamente, sin mediación alguna, con Dios: "un cristianismo de la pura interioridad" y, por ello, "un cristianismo si se quiere, protestante, protestante a ultranza", en palabras de Inciarte (2016: 133). Como se ha anticipado, estos dos atributos del protestantismo son expresados por Malick a través dos recursos poéticos, característicos de su peculiar estilo cinematográfico - llevado al extremo en sus últimos tres largometrajes de ficción: El árbol de la vida, To the Wonder y Knight of Cups-, a saber, el protagonismo del montaje sobre la imagen, como expresión de la oposición dialéctica entre naturaleza y gracia, y el constante recurso a la voz en off, como expresión de la primacía de la subjetividad.

En el caso montaje, podría afirmarse que, si bien el cine Tarkovski lo reduce a su mínima expresión ${ }^{12}$, el de Malick sigue la dirección opuesta: es una práctica habitual del cineasta texano filmar horas y horas de metraje que luego son moldeadas en la sala de montaje (Kendrick, 2016). A diferencia del cineasta ruso, no es la presión temporal que se da dentro de cada plano la que marca el tempo del filme, sino un montaje fragmentado - lo que no quiere decir discontinuo-, cuyo principio configurador no es la unidad del conjunto, sino la oposición dialéctica. Esta es, en síntesis, la estrategia poética con la que Malick crea significado, especialmente en su última etapa: a diferencia

12 "Tampoco se puede asentir a la idea de que el montaje es el elemento más importante para dar forma a la película, de que la película surge en el montaje [...]. La imagen fílmica surge en los planos y existe dentro de cada uno de ellos" (Tarkovski, 1991: 140). 
de la imagen icónica, donde todo comparece en la superficie, el sentido del filme de Malick surge de la oposición dialéctica, generada por el montaje. El árbol de la vida es, posiblemente, el mejor ejemplo de esta forma de montaje dialéctico, que se concreta -además de en sus secuencias de montaje, como la del nacimiento de Jack, especialmente representativa - en la gran contraposición, mostrada a lo largo de la primera mitad de la película, entre las imágenes cotidianas de la vida de la familia O’Brien, en los años 50, y las imágenes de la creación del cosmos.

Solo mediante esta contraposición se revela el sentido del filme, parejo al que presenta el Libro de Job, citado directamente en la película al menos tres veces ${ }^{13}$ : tal y como sostiene Leithart, estas citas sugieren "que la película será una meditación sobre el sufrimiento y la muerte, y particularmente sobre el sufrimiento y la muerte injustos" (2013: 12). En concreto, todo el relato pivota sobre la muerte de R.L., uno de los hermanos O'Brien, fallecido a los diecinueve años - la película no indica la causa del fallecimiento, aunque parece tratarse de una muerte en combate-, así como sobre la rebeldía contra Dios de Jack O'Brien (Hunter McCracken/Sean Penn) frente al sufrimiento de los inocentes — sus iniciales no son casualidad (J.O.B.) — y la incomprensión de Mrs. O’Brien (Jessica Chastain) frente a la repentina muerte de su hijo. Del mismo modo que, a las preguntas de Job acerca de su sufrimiento, Dios le responde con más preguntas sobre el milagro incom-

${ }^{13} \mathrm{Al}$ comienzo, como ya se ha indicado, pero también en el diálogo de la abuela (Fiona Shaw) con Mrs. O’Brien (Jessica Chastain) — “El Señor me lo dio, el Señor me lo quitó; bendito sea el nombre del Señor" (Job 1, 21) — y en el sermón del ministro episcopaliano. 
prensible de la creación - “¿Dónde estabas tú cuando yo cimentaba la tierra...?” (Job 38, 4)—, el montaje dialéctico de Malick traslada a las imágenes este mismo enfrentamiento. Frente a la pregunta de Mrs. O'Brien “¿Dónde estabas tú?” (“Where were you?”)—, la película responde con las imágenes de la creación, de una belleza sobrecogedora. Queda aquí patente cómo el sentido que subyace a El árbol de la vida no está tanto en sus imágenes, sino más bien en la contraposición de dichas imágenes, aparentemente irreconciliables.

Otra contraposición desarrollada por la película, esta vez en un plano más narrativo, es la que se da entre los personajes de Mrs. O’Brien, la madre de Jack, y Mr. O’Brien, su padre (Brad Pitt). Cada uno encarna uno de los dos principios aludidos al comienzo de la película por la voz en off de la madre: la gracia (la madre) y la naturaleza (el padre). Así, frente a la actitud de amor, humildad, agradecimiento y asombro de la primera se opone la arrogancia y la vanagloria del segundo. Estas dos actitudes son trasladadas por Malick al plano visual: en las escenas protagonizadas por la madre, la luz irradia todas las cosas, y la cámara parece flotar en torno a los personajes -incluso, en una escena muy simbólica, la madre levita sobre el jardín de la casa-; en cambio, en las escenas protagonizadas por el padre se advierte un predominio del claroscuro y una cámara más estática. El filme tampoco resuelve esta contraposición de opuestos: al contrario, esta se traslada al interior del hijo (Jack) y lo convierte en un personaje dividido. En palabras de Leithart:

Jack es el campo de batalla del conflicto entre naturaleza y gracia. Él llega a darse cuenta de que es una inestable amalgama de sus padres. "Padre, Madre. Siempre 
lucháis en mi interior, siempre lo haréis" ["Father, Mother. Always you wrestle inside me. Always you will']. Admite que la orientación de Mr. O'Brien hacia la 'naturaleza' es dominante en él. "Soy más como tú que como ella" ["Im more like you than like her"], le dice a su padre un poco más adelante (2013: 42).

Así pues, en lo que respecta a la construcción de los personajes, El árbol de la vida no presenta un término medio: o bien son personajes transidos de espiritualidad, figuras casi angélicas, como Mrs. O’Brien o R.L., o personajes irremisiblemente inclinados al pecado, lo quieran o no, como Mr. O’Brien o Jack.

En último término, este énfasis de la película sobre la contradicción que se da entre realidades irreconciliables puede ser interpretado desde la sensibilidad protestante $\mathrm{y}$, en especial, desde la llamada teología de la cruz, desarrollada principalmente por Lutero. Como apuntan Blanco y Ferrer, "la teología de la cruz es una teología dialéctica, de la exclusión, del aut-aut" (2016: 43). Frente a la llamada teología de la gloria, centrada en la Encarnación y más próxima a la sensibilidad icónica, la teología de la cruz pone el acento sobre la gravedad del pecado humano, al tiempo que presenta la sola gracia (sola gratia) como el único camino de salvación: "Todo es gracia, y solo gracia; o todo es pecado, y solo pecado" (Blanco y Ferrer, 2016: 48). En esta misma línea, Lutero sostiene que la razón es ciega e ignorante, incapaz de dar con una conciliación de los opuestos; únicamente la sola fe (sola fides) del sujeto, confiada en el amor y la misericordia de Dios, es capaz de superar ese abismo. "La subjetividad se convierte así en el punto de partida para interpretar toda la Revelación cristiana” (Blanco y Ferrer, 2016: 57). 
De modo análogo, el sentido propiciado por el montaje dialéctico no surge por sí mismo: ha de ser puesto ahí por la subjetividad del espectador. Así lo señala Paul Schrader cuando habla de la disparidad y la acción decisiva, rasgos propios de lo que él llama el estilo trascendental del cine: por un lado, la disparidad consiste en mostrar "la paradoja de lo espiritual dentro de lo físico" (Schrader, 1998: 106); una contraposición que, como se ha indicado, El árbol de la vida articula por medio del montaje. Entonces llega un punto en la película - la acción decisiva - donde, a través del lenguaje fílmico, se presenta al espectador un suceso increíble que permite la unidad de los opuestos. Es una situación imposible de ser abordada por ninguna explicación lógica, en la que "lo espiritual y lo físico pueden coexistir, aunque sea con tensión y de forma indecisa" (Schrader, 1998: 107). Esta situación no desvela su sentido completo al margen del espectador, sino que requiere de él "su participación y su consentimiento" (Schrader, 1998: 105); en otras palabras, le exige realizar un acto de fe que otorgue un sentido trascendente a las imágenes. En El árbol de la vida, la acción decisiva sería, posiblemente, su secuencia final: "Si Malick sigue a Job hasta el final —sostiene Leithart-, hasta el final de todos los finales al final de los tiempos, hemos de esperar escenas de restauración [restoration]" (2013: 83). En efecto, esta secuencia muestra el reencuentro de Jack O'Brien con toda su familia — también con su hermano fallecido - en la orilla de una playa, símbolo del final de los tiempos: el cielo nuevo y la tierra nueva descrita por san Juan en el Libro del Apocalipsis $(21,1)$. La secuencia es introducida por la oración en off de Jack - "Guíanos hasta el final de los tiempos" ("Guide us until the end of time")_ y el Agnus Dei perteneciente al Requiem de Berlioz. 
El segundo recurso poético empleado por el cineasta texano es el uso de la voz en off, que es "una característica predominante en todas las películas de Malick, aunque su función es cada vez más idiosincrásica" (Davies, 2009: 576). En sus dos primeros largometrajes, Malas tierras (Badlands, 1973) y Dias del cielo (Days of Heaven, 1978), el director dota a este recurso de un tono irónico, generado por el contraste entre la ingenua voz en off de sus protagonistas Holly (Sissy Spacek) y Linda (Linda Manz), respectivamente. Sin embargo, es a partir de La delgada linea roja (The Thin Red Line, 1998) cuando la voz en off adquiere un cariz poético — desprendiéndose de toda ironía, y de toda función narrativa- que reaparecerá en sus filmes posteriores.

Sin pretender un análisis pormenorizado de este recurso en El árbol de la vida, sirva apuntar cómo en esta película la voz en off cumple una función en parte novedosa en la obra de Malick, incoada por El nuevo mundo (The New World, 2005): es empleada a modo de oración; la oración de Mrs. O’Brien y de Jack, esta última convertida en monólogo durante la larga secuencia que narra su alejamiento de Dios cuando es casi un adolescente. De hecho, antes de que aparezca ningún personaje, durante ese plano inicial de una misteriosa luz anaranjada, ya suena una voz en off que más tarde reconocemos como la de Jack: "Hermano, Madre. Fueron ellos los que me llevaron a tu puerta" ("Brother, Mother. It was they who led me to your door"). En síntesis, en El árbol de la vida la voz en off es uno de los principales recursos con los que el cineasta dota de unidad y sentido al relato. De este modo, la subjetividad del personaje — de Mrs. O’Brien y Jack, sobre todo- se presenta, por así decir, como condición de posibilidad de la unidad del relato. 
En sintonía con las reflexiones de Inciarte sobre la sensibilidad protestante, el uso de la voz en off en El árbol de la vida puede ser visto como una expresión poética del subjetivismo al que tiende esta sensibilidad. Según explican Blanco y Ferrer, para el protestantismo "la relación con Dios queda teñida por el carácter dialógico e interpersonal (Cristo-creyente), por la que lo único importante es el encuentro personal con Dios", esto es, "la relación salvadora es entre un 'yo' y un 'Tú’” (2016: 47). Se acentúa, por consiguiente, la autonomía de la persona, que no depende de ninguna instancia intermedia - la Iglesia - para entrar en comunión con Cristo. "Un cristianismo de la pura interioridad", como decía Inciarte (2016: 133).

\section{Condusiones}

En presente análisis ha pretendido indagar las posibilidades de vincular el cine de Andréi Tarkovski y Terrence Malick con dos sensibilidades específicas, esto es, con dos modos de concebir el arte en relación con la fe cristiana. Como se ha apuntado, es el propio Inciarte quien, en su ensayo, relaciona al cineasta ruso con la sensibilidad icónica. En cambio, el vínculo entre el cine de Malick y la sensibilidad protestante — en tanto que análoga a la nestoriana- se ha presentado aquí como una hipótesis más arriesgada, dada la ausencia de aserciones del propio Malick acerca de la estética y la poética de su cine. No obstante, una vez concluido el análisis, la relación de la filmografía de Malick - y de El árbol de la vida, en especial- con el protestantismo se muestra, al menos, como una hipótesis con visos de ser verdadera. 
En ambos casos, tanto en el de Tarkovski como el de Malick, este análisis no ha discurrido por el plano conceptual (del qué) sino, más bien, por el plano formal (del cómo) o, como señala Inciarte, del concepto vivificado por la forma, esto es, del contenido elevado por la sensibilidad. En esta línea, Tarkovski sostiene que lo más específico del cine es su capacidad para sellar el tiempo en su pasar. Es este el medio por el que el arte cinematográfico hace suyo el carácter absoluto propio de la imagen icónica, en la que todo comparece en su densa superficie. Así, la superficie, la apariencia, del icono es lo único que no engaña, como decía Josef Albers. La película Stalker expresa este carácter icónico de varios modos: por un lado, el estatismo y el tempo lento de sus planos subrayan la cualidad temporal de las imágenes; por otro lado, la confluencia del tiempo real que dura la película y el tiempo ficticio de la acción - propiciada por la estructura narrativa del relato, configurado como un viaje - apunta en esta misma dirección. Además, el modo en que el personaje del Stalker concibe el viaje —aludiendo a la escena de los discípulos de Emaús del Evangelio según san Lucas - indica la necesidad de un camino de purificación de la mirada para contemplar la imagen icónica, para que esta sea una verdadera revelación tanto para los personajes como para el espectador.

La asociación del cine de Malick tampoco puede quedar limitada al plano conceptual, aunque esta exista de hecho, quizá de un modo más explícito que en la obra de Tarkovski. A este respecto, sirva recordar las numerosas citas directas de El árbol de la vida a determinados pasajes de la Biblia - los cuales iluminan, sin duda, el sentido de las imágenes- y a la fe cristiana (episcopaliana) de la familia O’Brien, remedo de la fe del cineasta texano. En el plano 
poético, se ha destacado el empleo de dos recursos centrales en la filmografía de Malick: el montaje fragmentado y el uso de la voz en off con una función no narrativa. En efecto, el montaje cumple un papel de gran relevancia en $E l$ árbol de la vida como recurso creador de sentido. Es por medio de la contraposición de realidades irreconciliables - la belleza de la creación del cosmos frente al sufrimiento de una madre por la pérdida de un hijo- como la película realza la contradicción, de modo análogo a como lo hace la teología de la cruz de Lutero. Al final del relato se le presenta al espectador una acción decisiva, en expresión de Schrader, que permite la reconciliación de los opuestos, aunque no por vía racional. En último término, es el espectador quien ha de aceptar en su interior esa reconciliación sugerida por la película: de esta forma, El árbol de la vida apela constantemente a la subjetividad del espectador como fuente de un sentido que ha de ser puesto por esa subjetividad. El segundo recurso poético analizado, la voz en off, remarca de nuevo la primacía de la subjetividad — de los personajes, en este caso-. Por primera vez, Malick emplea la voz en off a modo de oración, subrayando así la tendencia protestante al subjetivismo, es decir, a la relación directa entre la persona y Dios, sin mediación de ningún tipo.

Surge la pregunta, al término de este análisis, por la posibilidad de un cine que no sea totalmente icónico, pero que tampoco sea un cine de la contradicción —donde la conciliación de los opuestos solo pueda ser puesta, a modo de salto de fe, por la subjetividad del espectador-. Ambas sensibilidades son, como explica Fernando Inciarte, problemáticas: la sensibilidad icónica aspira a una meta inasequible a este mundo, una meta a la que el arte solo puede tender, sin llegar nunca a alcanzarla. Tampoco Tarkovski la al- 
canza del todo con su cine: por icónicas que sean sus imágenes, siempre hay algo en ellas que no acaba de comparecer. Por otro lado, la sensibilidad protestante no sale del planteamiento nestoriano, donde fe y cultura, arte y cristianismo, son realidades opuestas, que únicamente pueden ser conciliadas — sin llegar a conciliarse realmente- por la fe del sujeto que crea o contempla que es, en el largo plazo, una fe voluntarista.

El pensamiento estético de Inciarte — recogido hasta la fecha en Imágenes, palabras, signos (2004), La imaginación trascendental (2012) y Cultura y verdad (2016), principalmente- está orientado a recordar una verdad fundamental sobre el arte, capaz de salvar el peligro de caer en los extremos aquí descritos. Esta verdad - ligada inseparablemente a la condición creada de la realidad y, por consiguiente, a la concepción del tiempo real como puro instante presente - afirma que el mundo creado "ha pasado, pero, al mismo tiempo, no ha pasado, es y no es, está pasando, es paso, pascua” (Inciarte, 2016: 129). En esta misma línea, la relación entre fe y arte, entre cristianismo y cine, habría de darse siempre como "tensión vivificante" (2016: 142), sin quedar nunca solucionada.

\section{Bibliografia}

P. Blanco y J. Ferrer, Lutero 500 años después. Breve historia y teología del protestantismo, Madrid, Rialp, 2016.

D. Davies, "Terrence Malick", en: P. Livingston y C. Plantinga (eds.), The Routledge Companion to Philosophy and Film, Londres/Nueva York, Routledge, 2009, pp. 569-580.

N. Hay, "Cosmic Mourning: The Birth of Transcendence in Terrence Malick's Tree of Life”, en: TRANS-. Revue de littérature générale et comparée, 2014 (18). 
Sensibilidades enfrentadas

C. Heber-Percy, "Reimagining Faith. Hope and the Kingdom of God in Tarkovsky's Stalker: a modern spiritual journey into disaster, darkness, and redemption”. Texto de la comunicación presentada en la Film-Philosophy Conference 2016, University of Edinburgh.

F. Inciarte, "Qué y cómo o Sobre objetivismo y subjetivismo en el arte y su relación con diversas formas de vida", en: Cultura y verdad. Sobre lo objetivo y lo subjetivo en el arte, la vida y la filosofía (ed. L. Flamarique), Pamplona, EUNSA, 2016, pp. 27-161.

- La imaginación trascendental. En la vida, en el arte y en la filosofía (ed. M. A. Labrada), Pamplona, EUNSA, 2012.

-, Imágenes, palabras, signos. Sobre arte y filosofía (ed. L. Flamarique), Pamplona, EUNSA, 2004.

S. Kendall y T.D. Tucker, "Introduction", en: Terrence Malick. Film and Philosophy, Londres/Nueva York, Continuum, 2011, pp. 1-12.

J. Kendrick, “An Improbable Career. The Films of Terrence Malick”, en Ch. B. Barnett y C. J. Elliston (eds.), Theology and the Films of Terrence Malick, Londres/Nueva York, Routledge, 2016, pp. 3-28.

P.J. Leithart, Shining Glory: Theological Reflections on Terrence Malick's Tree of Life, Eugene (OR), Cascade Books, 2013.

P. Maher Jr. (ed.), One Big Soul. An oral history of Terrence Malick, Lulu.com, 2014.

J. Orellana y J. Martínez Lucena, Celuloide posmoderno. Narcisismo y autenticidad en el cine actual, Madrid, Encuentro, 2010.

J. Ratzinger, "La cuestión de las imágenes", en: El espiritu de la liturgia. Una introducción (trad. Raquel Canas), Madrid, Ediciones Cristiandad, 2001, pp. 155-175.

S. Rybin, Terrence Malick and the Thought of Film, Lanham (MD), Rowman \& Littlefield, 2012.

P. Schrader, El estilo trascendental del cine: Ozu, Bresson, Dreyer (trad. B. Viejo Viñas), Madrid, Ediciones JC Clementine, 1998. 
Pablo Alzola

M. Tarkóvskaya, testimonio recogido en: VV.AA, Acerca de Andréi Tarkovski, Madrid, Jaguar Ediciones, 1988.

A. Tarkovski, Esculpir en el tiempo. Reflexiones sobre el arte, la estética y la poética del cine (trad. E. Banús y J.M. Gorostidi), Madrid, Rialp, 1991.

Pablo Alzola Cerero

p.alzola@alumnos.urjc.es 


\section{PRIMERA EDICIÓN}


